\title{
Achieving the Circular Economy: Exploring the Role of Local Governments, Business and Citizens in an Urban Context
}

\author{
Jenny Palm ${ }^{1, *(D)}$ and Nancy Bocken ${ }^{1,2}$ \\ 1 International Institute for Industrial Environmental Economics (IIIEE), Lund University, P.O. Box 196, \\ SE-221 00 Lund, Sweden; nancy.bocken@maastrichtuniversity.nl \\ 2 Maastricht Sustainability Institute, School of Business and Economics, Maastricht University, \\ Tapijn 11 Building D, P.O. Box 616, 6200 MD Maastricht, The Netherlands \\ * Correspondence: jenny.palm@iiiee.lu.se; Tel.: +46-46-222-02-42
}

Citation: Palm, J.; Bocken, N. Achieving the Circular Economy: Exploring the Role of Local Governments, Business and Citizens in an Urban Context. Energies 2021, 14, 875. https://doi.org/10.3390/ en14040875

Received: 28 January 2021

Accepted: 4 February 2021

Published: 8 February 2021

Publisher's Note: MDPI stays neutral with regard to jurisdictional claims in published maps and institutional affiliations.

Copyright: (c) 2021 by the authors. Licensee MDPI, Basel, Switzerland. This article is an open access article distributed under the terms and conditions of the Creative Commons Attribution (CC BY) license (https:// creativecommons.org/licenses/by/ $4.0 /)$.

\section{Objectives of This Special Issue}

The urban context is an experimentation space to accelerate the transition to a circular economy. This Special Issue explores how and why cities engage in circularity. This Special Issue includes papers from different regions, on a variety of topics, using different methods and suggesting a multitude of tools. In sum, together they show the complexity that cities are facing, but they also provide insights into how circular cities may evolve in the future.

\section{Overview of the Papers Included}

Table 1 gives an overview of included articles and which scope, geographical focus, methods and tools the articles discuss.

The included papers cover a wide variety of topics and actors: governing modes, the textile industry, repair ecosystems for mobile phones, waste management, food producers and farmers markets, and citizens and climate change. The geographical focus is EU, USA and China. The research methods applied in the papers are also diversified, including both quantitative and qualitative approaches. Even if all papers discuss different challenges that cities and the circular economy are facing, they all end up being solution-oriented, with suggestions for tools to apply in the future. Below, the different papers are presented in more depth.

In the paper of Palm, Södergren and Bocken, "The Role of Cities in the Sharing Economy: Exploring Modes of Governance in Urban Sharing Practices" [1], the potential roles cities might have in governing the sharing economy is explored. Cities have provided space for various sharing initiatives such as car sharing, public libraries and repair workshops. The potential governing roles of cities in the sharing economy are discussed in relation to the experience in four Swedish cities: Stockholm, Gothenburg, Malmö and Umeå. Three dominant modes of governing were identified, namely: governing by provision and authority; governing by partnership and enabling; and governing through volunteering. The four studied cities applied all three governing modes, although with a primary focus on governing by authority and governing through partnership. When it comes to sharing projects characterized by governing through volunteering, it was always the local government initiating these projects, even if these projects were formally run by a non-governmental organisation '(NGO). One important conclusion from this paper is that it is important that cities reflect upon their powerful position, and, that in the case the city becomes too dominant, it might out-compete both businesses and initiatives from NGOs. 
Table 1. Papers in this Special Issue.

\begin{tabular}{|c|c|c|c|c|c|}
\hline Authors & Title & Scope/Actors & Country Focus & Method(s) & Tool(s)/Outcomes \\
\hline $\begin{array}{c}\text { Palm, } \\
\text { Södergren and } \\
\text { Bocken }\end{array}$ & $\begin{array}{l}\text { The Role of Cities in } \\
\text { the Sharing Economy: } \\
\text { Exploring Modes of } \\
\text { Governance in Urban } \\
\text { Sharing Practices }\end{array}$ & $\begin{array}{c}\text { Governing modes, } \\
\text { local governments, } \\
\text { cities }\end{array}$ & Sweden & $\begin{array}{c}\text { Workshops, } \\
\text { semi-structured } \\
\text { interviews and } \\
\text { participant } \\
\text { observation }\end{array}$ & Sharing solutions \\
\hline $\begin{array}{l}\text { Wang, Chen, } \\
\text { Cheng, Zhou, } \\
\text { Li and Yang }\end{array}$ & $\begin{array}{c}\text { Factorial } \\
\text { Decomposition of the } \\
\text { Energy Footprint of } \\
\text { the Shaoxing Textile } \\
\text { Industry }\end{array}$ & Textile industry & China & $\begin{array}{l}\text { Energy footprint } \\
\text { (EFP); Logarithmic } \\
\text { Mean Divisia } \\
\text { Index (LMDI) } \\
\text { Decomposition } \\
\text { Model }\end{array}$ & $\begin{array}{l}\text { Energy footprint (EFP) } \\
\text { indicator }\end{array}$ \\
\hline $\begin{array}{l}\text { Türkeli, Huang, } \\
\text { Stasik and } \\
\text { Kemp }\end{array}$ & $\begin{array}{l}\text { Circular Economy as a } \\
\text { Glocal Business } \\
\text { Activity: Mobile } \\
\text { Phone Repair in the } \\
\text { Netherlands, Poland } \\
\text { and China }\end{array}$ & $\begin{array}{l}\text { Repair ecosystems } \\
\text { for mobile phones } \\
\text { in countries }\end{array}$ & $\begin{array}{l}\text { Netherlands, } \\
\text { Poland and } \\
\text { China }\end{array}$ & $\begin{array}{l}\text { Questionnaire, } \\
\text { interviews, } \\
\text { comparison }\end{array}$ & $\begin{array}{l}\text { Insight into the repair } \\
\text { sector in The } \\
\text { Netherlands, China, } \\
\text { and Poland and policy } \\
\text { advice }\end{array}$ \\
\hline $\begin{array}{c}\text { Palafox- } \\
\text { Alcantar, Hunt } \\
\text { and Rogers }\end{array}$ & $\begin{array}{c}\text { A Hybrid } \\
\text { Methodology to Study } \\
\text { Stakeholder } \\
\text { Cooperation in } \\
\text { Circular Economy } \\
\text { Waste Management of } \\
\text { Cities }\end{array}$ & $\begin{array}{c}\text { Different } \\
\text { stakeholders in } \\
\text { waste management }\end{array}$ & UK & $\begin{array}{l}\text { Scenario Analysis; } \\
\text { Multi-Criteria } \\
\text { Decision Analysis; } \\
\text { and Game Theory }\end{array}$ & $\begin{array}{c}\text { Hybrid methodology } \\
\text { encouraging } \\
\text { cooperation in } \\
\text { decision-making } \\
\text { processes }\end{array}$ \\
\hline $\begin{array}{l}\text { Nogueira, } \\
\text { Ashton, } \\
\text { Teixeira, Lyon } \\
\text { and Pereira }\end{array}$ & $\begin{array}{l}\text { Infrastructuring the } \\
\text { Circular Economy }\end{array}$ & $\begin{array}{l}\text { Food producers } \\
\text { and farmers } \\
\text { markets }\end{array}$ & USA & $\begin{array}{l}\text { Participatory } \\
\text { action research, } \\
\text { co-creation, } \\
\text { material and } \\
\text { energy flow } \\
\text { analysis, life cycle } \\
\text { assessment, } \\
\text { network analysis, } \\
\text { systems dynamics } \\
\text { modeling, design } \\
\text { methods. }\end{array}$ & $\begin{array}{l}\text { Innovation model and } \\
\text { four I's model }\end{array}$ \\
\hline $\begin{array}{c}\text { Davidescu, } \\
\text { Apostu and } \\
\text { Paul }\end{array}$ & $\begin{array}{l}\text { Exploring Citizens' } \\
\text { Actions in Mitigating } \\
\text { Climate Change and } \\
\text { Moving toward Urban } \\
\text { Circular Economy. A } \\
\text { Multilevel Approach }\end{array}$ & $\begin{array}{l}\text { Citizens and } \\
\text { climate change }\end{array}$ & $\begin{array}{l}\text { All EU member } \\
\text { states }\end{array}$ & $\begin{array}{l}\text { Multi-Level } \\
\text { Econometric } \\
\text { Modelling; logistic } \\
\text { regression analysis }\end{array}$ & $\begin{array}{l}\text { Encouraging citizens } \\
\text { to take action }\end{array}$ \\
\hline $\begin{array}{l}\text { Zaleski and } \\
\text { Chawla }\end{array}$ & $\begin{array}{l}\text { Circular Economy in } \\
\text { Poland: Profitability } \\
\text { Analysis for Two } \\
\text { Methods of Waste } \\
\text { Processing in Small } \\
\text { Municipalities }\end{array}$ & $\begin{array}{l}\text { Waste processing, } \\
\text { incineration and } \\
\text { torrefaction }\end{array}$ & Poland & $\begin{array}{l}\text { Case study, } \\
\text { scenarios, } \\
\text { comparison, } \\
\text { profitability } \\
\text { analysis }\end{array}$ & $\begin{array}{c}\text { Torrefaction } \\
\text { (Torrefaction changes } \\
\text { biomass properties to } \\
\text { provide a better fuel } \\
\text { quality for combustion } \\
\text { and gasification) }\end{array}$ \\
\hline
\end{tabular}

Wang, Chen, Cheng, Zhou, Li and Yang's paper, "Factorial Decomposition of the Energy Footprint of the Shaoxing Textile Industry" [2], calculates the energy footprint (EFP) from textile production using Shaoxing's textile industry as a case study. The analysis focuses on the relationship between economic growth and environmental pressure. The analysis showed that from 2005 to 2018, the EFP first increased and then decreased. The authors conclude that Shaoxing's textile companies could accelerate the production of ecological textiles and promote clean production, printing and dyeing technologies. 
The local government could, together with social investors, contribute by initiating an innovation fund. Another suggestion by the authors is that Shaoxing's government should use their authority and close down printing and dying companies that consume significant amounts of energy and generate high levels of emissions. The authors also indicate the importance of developing policies with the aim to promote high value-added textile product manufacturing with less energy intensity.

Türkeli, Huang, Stasik and Kemp's article, titled "Circular Economy as a Glocal Business Activity: Mobile Phone Repair in the Netherlands, Poland and China" [3], looks into the repair of mobile phones. Repairing mobile phones is an excellent example of circular economy in an urban setting. This repair business does not only extend the lifetime of the phone, but also reduces the need for virgin materials used for constructing new phones. The authors embed the study in earlier research on firm level competitiveness and closed-loop design through repair. The focus for the analysis is the business ecosystem of independent mobile phone repair shops in three countries, the Netherlands, Poland and China, where questionnaires have been sent out to repair shops. The findings show that maintaining business' direct contact with customers is vital to sustain trust. The challenges the repair shops faced differed between the countries. In China, high cost for spare parts and low prices on new mobile phones were central, while the Netherlands and Poland experienced big challenges with competition from informal repair activities and new repair shops.

Palafox-Alcantar, Hunt and Rogers, in their paper titled "A Hybrid Methodology to Study Stakeholder Cooperation in Circular Economy Waste Management of Cities" [4], study the waste management of cities from a circular economy perspective and discuss how efficient waste management process resources can be fed back into the consumption process rather than reach an end-of-life. The contribution of the paper is to identify how collaboration can be engendered using a hybrid Game Theory approach, including scenario analysis and multi-criteria decision analysis. A case study of Birmingham in the UK is presented. The results show, for example, that cooperation needs to be embedded in circular economy adoption. A decision-making tool, such as the one presented in the paper, can be an important means to support this.

Nogueira, Ashton, Teixeira, Lyon and Pereira's paper, "Infrastructuring the Circular Economy" [5], discusses the need to reconfigure both hard (material and tangible aspects) and soft infrastructure (institutions, intangible aspects, and social behavior) to achieve efficient material resource cycling. The authors develop a new framework and a model including the range of resources organizations utilize when creating value for the organization, society, or the planet. Participatory action research methods are used in co-creation processes to synthesize knowledge on hard and soft infrastructures in relation to urban food producers and farmers markets in Chicago. The authors conclude that using a relational perspective gives insights into new opportunities for city interventions, where the different actors embedded in a situation become the means through which resources are mobilized and activated. By including dynamic interactions, cities can better understand how these interactions shape an infrastructural intervention for the circular economy and, by that, cities can also actively influence how to combine different types of resources to generate a sustainable transition.

Davidescu, Apostu and Paul focus on citizens in their paper titled "Exploring Citizens' Actions in Mitigating Climate Change and Moving toward Urban Circular Economy. A Multilevel Approach" [6]. The paper investigates why people engage in certain activities to contest climate change and choose to adopt more actions than others to mitigate climate change. The data used in the paper come from the cross-national dataset Eurobarometer and a study covering residents in all EU member states aged 15 years and over. In total, 27,655 individuals were interviewed, and of these, 18,529 were individuals from urban areas. The results show that climate change was perceived to be a very serious problem by most of the respondents. Many citizens declared that they have personally taken action to fight climate change; $25 \%$ of the respondents declared that they have taken more than five 
actions and $1 \%$ of the individuals declared that they have taken nine or more actions to mitigate climate change. The authors conclude that it is important to also consider citizens' attitudes towards climate change when developing strategies for circular cities.

Zaleski and Chawla, in their paper "Circular Economy in Poland: Profitability Analysis for Two Methods of Waste Processing in Small Municipalities" [7], discuss the implementation of the circular economy paradigm in Poland. Even if Poland has been successful in reducing the volume of generated waste during the last few decades, over $42 \%$ of waste is still being land-filled. In the article, profitability analysis is carried out for two methods of waste processing, namely incineration and torrefaction. The results show that torrefaction is a more desirable waste processing option as a step towards the implementation of the circular economy in the urban context. Torrefaction is also more profitable compared to incineration. Poland has so far not implemented any torrefaction plants on a large-scale basis for processing municipal waste, but this is something that Zalesk and Chawla recommend Poland to consider, which would be in line with the country's strategy to achieve a circular economy.

\section{Conclusions}

This Special Issue included interdisciplinary papers on a variety of topics and sectors: governing modes, the textile industry, repair ecosystems for mobile phones, waste management, food producers and farmers markets, and citizens and climate change. The geographical focus was mainly Europe, but China and the US were also studied. The authors of this Special Issue have illuminated a multitude of topics, methods, tools and perspectives that need to be included when exploring how circular cities can evolve today and in the future.

The lessons learned from the papers are manifold. First, cities have a multitude of tools to govern the circular economy. As shown by Wang et al., they can encourage circular initiatives by, for example, institutionalizing an innovation fund or using their authority to close down activities leading to major emissions. The potential positive role of city governments for the circular economy is undisputed, but Palm et al. showed that city governments also need to reflect upon their power and ensure that their strategies and goals do not outcompete civic society and their engagement. Second, the need for cooperation between actors was highlighted in several papers. A decision-making tool was suggested by Palafox-Alcantar et al., while Türkeli et al. emphasized the need for repair shops to establish direct contact with their customers and create trust. Nogueira et al. suggested that by embedding different actors (not only the usual suspects) in an activity, cities can actively contribute so that new cooperation and resource flows develop. Moreover, Davidescu et al. highlighted the need to also include citizens when developing strategies for circular cities. Third, the importance of reducing waste was also a recurring issue in the papers. Zaleski and Chawla focused on waste processing and found that torrefaction was more profitable than incineration and also a good choice for small cities striving to achieve a circular economy.

Finally, the papers covered a range of circular economy strategies, including repair to extend product lifetimes and slow resource loops; waste management approaches to recycle materials and close resource loops; and energy reduction per product and processes to narrow resource loops. By highlighting specific resource strategies, tools, methods and actors to involve, the papers contribute to our understanding of what a circular city could constitute and how it could emerge in the future. Yet, the papers are only starting to scratch the surface of the methods, approaches and collaborations needed to put the circular economy into practice. A diverse range of solutions and collaborations would need to co-exist to implement the circular economy in practice. To conclude, this Special Issue aims to inspire and give a solid base for further investigations of and experimentation with new solutions for circular cities.

Author Contributions: Both authors have contributed equally to this editorial. Both authors have read and agreed to the published version of the manuscript. 
Funding: We would like to acknowledge the funding by the Swedish Energy Agency project no 46016-1 "Smart symbiosis-collaboration for common resource flows".

Institutional Review Board Statement: Not applicable.

Informed Consent Statement: Not applicable.

Data Availability Statement: Not applicable.

Conflicts of Interest: The authors declare no conflict of interest.

\section{References}

1. Palm, J.; Södergren, K.; Bocken, N. The Role of Cities in the Sharing Economy: Exploring Modes of Governance in Urban Sharing Practices. Energies 2019, 12, 4737. [CrossRef]

2. Wang, X.; Chen, X.; Cheng, Y.; Zhou, L.; Li, Y.; Yang, Y. Factorial Decomposition of the Energy Footprint of the Shaoxing Textile Industry. Energies 2020, 13, 1683. [CrossRef]

3. Türkeli, S.; Huang, B.; Stasik, A.; Kemp, R. Circular Economy as a Glocal Business Activity: Mobile Phone Repair in the Netherlands, Poland and China. Energies 2019, 12, 498. [CrossRef]

4. Palafox-Alcantar, P.G.; Hunt, D.V.; Rogers, C.D. A Hybrid Methodology to Study Stakeholder Cooperation in Circular Economy Waste Management of Cities. Energies 2020, 13, 1845. [CrossRef]

5. Nogueira, A.; Ashton, W.; Teixeira, C.; Lyon, E.; Pereira, J. Infrastructuring the Circular Economy. Energies 2020, $13,1805$. [CrossRef]

6. Davidescu, A.A.; Apostu, S.-A.; Paul, A. Exploring Citizens' Actions in Mitigating Climate Change and Moving toward Urban Circular Economy. A Multilevel Approach. Energies 2020, 13, 4752. [CrossRef]

7. Zaleski, P.; Chawla, Y. Circular Economy in Poland: Profitability Analysis for Two Methods of Waste Processing in Small Municipalities. Energies 2020, 13, 5166. [CrossRef] 